UDC 678.01

\title{
PHYSICAL AND MECHANICAL PROPERTIES OF NANOCOMPOSITES BASED ON BLOCK COPOLYMER PROPYLENE WITH ETHYLENE AND GRAPHITE
}

\author{
${ }^{1}$ N.T. Kakhramanov, ${ }^{1}$ G.Sh. Gasimova, ${ }^{2}$ S.S. Pesetskiy, ${ }^{3}$ J.N. Kakhramanly, \\ ${ }^{3}$ R.V. Gurbanova, ${ }^{3}$ R.Sh. Hajiyeva, ${ }^{3}$ E.I. Suleymanova \\ ${ }^{1}$ Institute of Polymer Materials of ANAS \\ S.Vurgun Str., 124, Sumgait AZ5004, Azerbaijan,e-mail: gulnara.qasimova.68@mail.ru \\ ${ }^{2}$ V.A.Belyi Metal-Polymer Research Institute of the National Academy of Sciences of Belarus \\ Kirov str. 32a, Gomel, 246050, Belarus Republic \\ ${ }^{3}$ Azerbaijan State University of Oil and Industry \\ Azadlig ave., 20, AZ 1010 Baku, Azerbaijan
}

Received 16.12.2018

\begin{abstract}
The effect of concentration and size of fine dispersed particles of graphite on ultimate tensile stress, elongation at break, melt flow rate, and wear resistance of composite materials based on propylene block-copolymer with ethylene was considered. The possibility of essential improvement of the properties of nanocomposites was shown by means of crosslinking reaction in the dynamic mode. Using the method of thermo-mechanical analysis, the transition regularities of nanocomposites from solid to viscous state were investigated. Also, optimal concentrations of the reacting components were established to achieve the highest physic-mechanical properties of nanocomposites.

Keywords: block copolymer, graphite, thermo-mechanics, nanocomposites, ultimate tensile stress.

Doi.org/10.32737/2221-8688-2019-1-72-80
\end{abstract}

\section{INTRODUCTION}

Today polymer materials are used in any branch of industry. This was due to the use of various methods of chemical, mechanical and physical-chemical modification of base polymers following which the scope of changes in their physical-mechanical and operational characteristics was significantly expanded. [13]. Polyolefins (PO) are of the largest-capacity, available and wanted out of the entire range of polymers produced by industry. Therefore, the search for technical solutions aimed at improving the properties of polyolefins and the creation of new types of related composite materials is an important task. One of the ways to improve the mechanical properties of polyolefins is the introduction into the industry of nanofillers with their high efficiency and relatively low content in the composite material which makes it possible to expect significant economic feasibility of this approach.[4-6].

As for polyolefins, the propyleneethylene block copolymer (BEP) is one of the least-studied polymers, so the interest in this material deepens from year to year. In spite of the fact that polyolefins are produced in sufficient quantities worldwide and have a wide range of properties, their assortment does not always satisfy the constantly increasing requirements in the processing of plastics. Thus, the introduction of modern dispersed and fibrous fillers into polyolefins, especially nanoparticles based on mineral substances and layered silicates, has not been fully studied and causes some difficulties during their processing [6].

This work sets a task of addressing comprehensively physical-mechanical properties, regularities of formation of composite materials' structure based on polyolefins in the presence of a number of additives (including nanodispersed).

The aim of the work is to develop new approaches to the creation of composite materials based on propylene-ethylene block copolymer with nanodispersed graphite which are noted for their high physical-mechanical properties and wear resistance. 


\section{EXPERIMENTAL PART}

The propylene-ethylene block copolymer brand HB240P (BEP) is a chain of propylene molecules interrupted by a chain of propylene-ethylene copolymer. They are characterized by high impact strength (at low temperatures) and high elasticity; increased long-term thermal stability; resistance to thermal-oxidative destruction during the production and processing of polypropylene, as well as the use of related products. BEP has the following properties: breaking stress - 25.6 $\mathrm{MPa}$, elongation at break - $200 \%$, melt flow index $-0.61 \mathrm{~g} / 10 \mathrm{~min}$, Vicat softening point $-148^{\circ} \mathrm{C}$, melting point $-166^{\circ} \mathrm{C}$.

Graphite is one of the allotropic modifications of carbon and noted for layered structure. The layers of the crystal lattice are located one to another to form a number of structural modifications with symmetry from hexagonal syngony to trigonal. The layers are slightly wavy, practically flat, and composed of hexagonal layers of carbon atoms. The crystals are lamellar, scaly to form leafy and rounded radial-radiant units, rare - units of concentriczonal structure. Coarse crystalline precipitates often have a triangular hatch on the (0001) planes. As the object of study, there was used graphite with particles sized 20-110 nm, 450$1000 \mathrm{~nm}$ and $1500-3500 \mathrm{~nm}$.

The size of graphite particles was determined on a device of model STA PT1600 Linseiz Germany.

Dicumyl peroxide (PD) is a light-yellow powder, $\mathrm{Tm}=40{ }^{\circ} \mathrm{C}$, designed to produce crosslinked structures in polymer blends.

The method of obtaining polymer composites. Carefully weighed samples of the polymer matrix and nano-dispersed filler powder are mixed on hot rollers at $140-180^{\circ} \mathrm{C}$ for 7-8 minutes. The resulting composites are pressed at $180-190^{\circ} \mathrm{C}$. The dumb bell samples are cut down from the obtained plates to study the physical-mechanical characteristics of polymer nanocomposites in accordance with GOST 17370-71.

When constructing the thermo-mechanical curve of the polymer $\Delta=\mathrm{f}(\mathrm{T})$, it is very important to cover, as far as possible, the entire temperature range of the polymer - glassy (crystalline), highly elastic and viscous states. Thermo-mechanical curves reflect all possible physical, physical-chemical and chemical processes occurring in the sample as a result of changes in the experiment temperature and, thus, provide reliable information on temperature transitions that are important for polymer processing.

Physical-mechanical characteristics were determined by standard methods: yield strength under tension and elongation at break in accordance with GOST 11262-80.

The gel fraction of cross-linked BEP-based samples was separated on a Soxhlet instrument by washing the samples at the boiling point of o-xylene. The difference in mass of the sample before and after washing was determined by the content of the gel fraction.

The melt flow rate (MFR) was determined on rheometer of the brand MELT FLOW TESTER, CEAST MF50 (INSTRON, Italy) at $190^{\circ} \mathrm{C}$ and load of $5 \mathrm{~kg}$. The wear resistance of the composites was investigated on abrazimeter. Path length is $44 \mathrm{~m}$, load $6 \mathrm{~N}$, abrasive paper P500.

\section{RESULTS AND DISCUSSION}

It is obvious that the strength of polymer dispersions mainly depends on the properties and structural features of the original polymer matrix, the method of interaction of solid particles of the filler with the dispersed medium, the concentration and size of particles. In this regard, this paper focuses on the study of the effect of concentration and particle size of graphite on the main physical-mechanical properties of the composite material. The choice of nanodispersed graphite as a filler was driven by the need to improve the wear resistance of the BEP-based composite material while maintaining the physical-mechanical and technological characteristics at a satisfactory level. 
At the same time, it was important to study the effect of graphite particle size on properties. Such approach to the study of composite materials will allow taking more concentrated approach to their development together with a subsequent prediction of the possibility of their practical use in various industries.

Table 1. The effect of concentration and particle size of graphite on the properties of BEP-based composites

\begin{tabular}{|c|c|c|c|c|c|c|}
\hline № & $\begin{array}{c}\text { Formula of } \\
\text { polymer composite } \\
(\mathrm{BEP}+\mathrm{wt} \% \\
\text { graphite })\end{array}$ & $\begin{array}{c}\text { Ultimate } \\
\text { tensile stress, } \\
\mathrm{MPa}\end{array}$ & $\begin{array}{c}\text { Elongation } \\
\text { at break, } \\
\%\end{array}$ & $\begin{array}{c}\text { MFI, } \\
\text { g/10min }\end{array}$ & $\begin{array}{c}\text { Wear in } \\
\text { the first } \\
\text { cycle, } \\
\text { mg }\end{array}$ & $\begin{array}{l}\text { Particle } \\
\text { size, } \\
\text { nm }\end{array}$ \\
\hline 1 & BEP & 25.6 & 200 & 0.61 & 144.12 & - \\
\hline 2 & $\mathrm{BEP}+1.0$ & 42.5 & 240 & 3.17 & 57.25 & $20-110$ \\
\hline 3 & $\mathrm{BEP}+5.0$ & 40.4 & 195 & 6.33 & 40.37 & $20-110$ \\
\hline 4 & $\mathrm{BEP}+10.0$ & 37.3 & 125 & 7.25 & 38.15 & $20-110$ \\
\hline 5 & $\mathrm{BEP}+20.0$ & 33.6 & 80 & 6.12 & 34.59 & $20-110$ \\
\hline 6 & $\mathrm{BEP}+30.0$ & 31.7 & 40 & 5.15 & 39.18 & $20-110$ \\
\hline 7 & $\mathrm{BEP}+1.0$ & 39.2 & 205 & 3.05 & 64.52 & $450-1000$ \\
\hline 8 & $\mathrm{BEP}+5.0$ & 38.6 & 180 & 4.98 & 47.46 & $450-1000$ \\
\hline 9 & $\mathrm{BEP}+10.0$ & 36.8 & 90 & 5.36 & 41.66 & $450-1000$ \\
\hline 10 & $\mathrm{BEP}+20.0$ & 30.2 & 70 & 3.88 & 38.75 & $450-1000$ \\
\hline 11 & $\mathrm{BEP}+30.0$ & 26.5 & 35 & 2.59 & 39.31 & $450-1000$ \\
\hline 12 & $\mathrm{BEP}+1.0$ & 28.3 & 185 & 2.54 & 73.86 & $1500-3200$ \\
\hline 13 & $\mathrm{BEP}+5.0$ & 29.7 & 120 & 3.67 & 65.41 & $1500-3200$ \\
\hline 14 & $\mathrm{BEP}+10$ & 28.5 & 85 & 3.74 & 54.19 & $1500-3200$ \\
\hline 15 & $\mathrm{BEP}+20$ & 24.7 & 50 & 1.99 & 44.95 & $1500-3200$ \\
\hline 16 & $\mathrm{BEP}+30$ & 21.3 & 20 & 0.95 & 46.73 & $1500-3200$ \\
\hline
\end{tabular}

Table-1 presents the results of the study into complex properties of BEP filled with graphite. At the same time, graphite samples with particle sizes from nanoscaled $(20-110 \mathrm{~nm})$ to dispersed (1500-3200 nm) were used. It was important to find out which properties are most affected by the influence of the particle size of graphite. The analysis of the data presented in this Table, regardless of the particle size, makes it possible to infer that the introduction of even 1.0 wt.\% graphite leads to essential rise in ultimate stress limit and even elongation at break. At the same time, nanocomposites are notable for the best properties at every measure. As can be seen from the Table, for composites with a particle size of graphite up to $1000 \mathrm{~nm}$, the maximum strength is achieved at $1.0 \mathrm{wt} . \%$ of its content. In composites with a particle size of graphite of 1500-3200 nm, the maximum strength of the samples was established at 5.0 wt. $\%$ of graphite content. There are grounds to believe that the smaller is the particle size of the filler, the lower is the concentration of the filler to reach maximum effect in improving the ultimate tensile stress. A further increase in the concentration of the filler leads to a regular decrease in the breaking stress and elongation at break of the samples. As a rule, the surface of active filler particles has a sufficiently high adsorption capacity following which macrochain segments are fixed on it. In this case, the macrosegment is oriented toward the surface of the particles to form a monolayer. It is possible that on the surface of the first monolayer, to a lesser extent though, the orientation of the macrosegments takes place as well. As for the volume of the polymer matrix, the orientation processes will weaken. Based on this, it can be assumed that the stronger is the adhesive interaction in the polymer-filler system, the greater is the thickness of the formed interfacial layer. In other words, a 
somewhat ordered and partially oriented interfacial layer appears in the polymer matrix. In this case, the interfacial layer is a monolayer adjacent to the "polymer-filler" interface which by its structure and properties may differ from those located in the polymer volume. In addition, the smaller is the size of the filler particles, the greater is their number per unit volume of the polymer matrix. That is why in nanocomposites, the greatest effect in increasing the breaking stress is achieved with a minimum concentration of the filler [7-9]. It is possible that at low concentrations of graphite, the resulting heterogeneous nucleation centers, along with homogeneous ones, are potential centers for the formation of fine spherulite crystalline formations. It should be noted that the nanoparticles are similar in size to that of the primary crystalline formations - "crystallites", and therefore the probability of their incorporation into the crystalline structure of the polymer matrix is not excluded not only because of the formation of heterogeneous crystallization centers. With a decrease in the particle size of graphite, its specific surface area increases to improve the adhesion contact with the BEP macrochains and the formation of the interfacial layer. We believe that with an increase in the filler concentration, the growth of crystalline formations is accompanied by the displacement of an excess of particles into the amorphous region which together represents an inter-spherolite space consisting of a multitude of "through passage" chains responsible for deformation processes in the process of uniaxial stretching. And as the filler particles accumulate in the inter-spherolite space, the conformational processes and the segmental mobility of the flow chains are significantly hampered, resulting in the deterioration of the elongation at break and deformation properties of composite materials.

It is characteristic that, regardless of the size of the filler particles, the introduction of graphite leads to noticeable increase in the MFI

The choice of this object was due to the need to use not only its high strength properties, but also a high wear resistance. Analysis of the data presented in the Table above shows that the use of DP as a crosslinking agent significantly affects the structure and properties of of the composites. The latter circumstance is interpreted by the fact that graphite has a layered structure that, to a certain extent, with the uniaxial direction of the melt flow of the composite under shear stress, will accelerate the melt flow process. At the same time, an interesting feature was established in the change MFI of composites. For example, as nanoparticles in the polymer mass increase to 20 wt. \% there is a noticeable increase in MFI samples. Note that further increase in the concentration of graphite nanoparticles leads already to a certain decrease in the MFI of the samples, although their value remains higher than that of the original BEP. At the same time, the maximum value of the MFI in composites with a particle size of $450-1000 \mathrm{~nm}$ and higher, this effect is achieved when the concentration of graphite is not more than $10 \mathrm{wt}$ \%.In any case, the fact that the MFI samples are kept at a sufficiently high level indicates a slight degree of agglomeration of graphite particles in the melt of the polymer matrix.

Another important parameter is the wear resistance considered objects of study. In this case, the introduction of even $1.0 \mathrm{wt}$. \% graphite leads to a significant reduction in wear of composite materials. For example, at the minimum concentration of graphite, the wear resistance of nanocomposites increases by about 2.5 times, i.e. their wear is reduced by the same figure. For composites with a particle size of 450-1000 nm, the wear resistance increases 2.23 times, in samples with a particle size of 1500$3200 \mathrm{~nm}$ the value of this parameter rises by 1.95 times. Regardless of the particle size, a further increase in the concentration of graphite in the composition of BEP leads to an increase in wear resistance and a decrease in wear of the composite material.

To obtain new types of polymer nanocomposites, it was interesting to study the effect of various cross-linking agents on the nature of changes in their structure and operational characteristics.

nanocomposites. In the process of crosslinking the initial polymer matrix (BEP), a regular deterioration in the elongation at break of the samples is observed, which, most likely, may be due to the formation of a spatial structure, which is in the process of crystallization, so the growth 
of crystalline formation is displaced into the inter-spherulite amorphous region. As a result, in the process of cooling and the completion of the crystallization process of the polymer matrix, the spherulitic structures are, like a web, enveloped with cross-linked macrochains.

Table 2. Effect of DP concentration on the crosslinking process and properties of nanocomposites based on BEP and graphite

\begin{tabular}{|l|l|c|c|c|c|c|}
\hline № & $\begin{array}{l}\text { Formula of polymer } \\
\text { composite (BEP + wt.\% } \\
\text { graphite +wt.\% DP) }\end{array}$ & $\begin{array}{c}\text { Ultimate } \\
\text { tensile stress, } \\
\text { MPa }\end{array}$ & $\begin{array}{c}\text { Elongation } \\
\text { at break, \% }\end{array}$ & $\begin{array}{c}\text { MFI, } \\
\text { g/10min }\end{array}$ & $\begin{array}{c}\text { Wear in } \\
\text { the first } \\
\text { cycle, } \\
\text { mg }\end{array}$ & $\begin{array}{c}\text { Гель- } \\
\text { фракция } \\
\% \text { wt. }\end{array}$ \\
\hline 1 & BEP+0.2DP & 26.3 & 145 & 0.47 & 131.34 & 11 \\
2 & BEP+0.5DP & 28.2 & 125 & 0.32 & 123.13 & 25 \\
3 & BEP+1.0DP & 24.9 & 20 & Don't flow & 101.76 & 51 \\
4 & BEP+2.0DP & 15.4 & - & Don't flow & 129.06 & 85 \\
5 & BEP+10 Gr+0.2DP & 40.5 & 95 & 0.85 & 45.21 & 9 \\
6 & BEP+10Gr+0.5DP & 41.6 & 45 & 0.41 & 31.49 & 22 \\
7 & BEP+10Gr+1.0DP & 32.7 & 15 & 0.14 & 49.38 & 49 \\
8 & BEP+10Gr+2.0DP & 19.8 & - & Don't flow & 103.74 & 83 \\
\hline
\end{tabular}

*graphite - abbreviated $\mathrm{Gr}$

Such a structural organization, of course, affects the deterioration of the conformational mobility of the walk-through chains and, consequently, a decrease in the elongation at break [10,11]. When evaluating ultimate tensile stress, chemical crosslinking favourably affects the value of this parameter at relatively low concentrations of DP equal to $0.2-0.5 \mathrm{wt} . \%$. With a higher concentration of a crosslinking agent, all properties are deteriorated except for wear resistance. Some decrease in the wear of the material in the process of crosslinking with the concentration of DP up to $1.0 \mathrm{wt} . \%$ can be interpreted by increasing the strength of the samples. At the same time, with the introduction of $2.0 \%$ of the mass. PD is a complete interruption of the crystal structure of BEP with the formation of an amorphous cross-linked polymer following which the strength and wear resistance of the latter deteriorate sharply, which confirms our arguments. As a result of X-ray analysis, it was found that the degree of crystallinity of BEP after crosslinking by 2.0 wt.\% DP is practically absent.

In the presence of graphite nanoparticles, the process of macrochains crosslinking at concentrations of DP equal to 0.2-0.5 wt.\% favourably affects changes in the properties of nanocomposites. Apparently, it would be correct to say that, at low concentrations of DP, the rare-mesh structure does not encompass the frontier monolayer adjacent to the nanoparticle surface, since otherwise it would lead to interruption of the adhesive contact of the polymer-filler which predetermines the high deformation-strength properties of nanocomposites. At higher DP concentrations (over $1.0 \mathrm{wt} . \%$ ), a large part of the polymer matrix is cross linked, including the nearboundary monolayer, since only highly crosslinked structure leads to a sharp deterioration of the ultimate tensile stress and elongation at break of nanocomposites. The increase in the gel fraction to $83-85 \mathrm{wt}$. \% with the introduction of $2.0 \mathrm{wt} . \% \mathrm{DP}$ is proof of that.

As can be seen from Table 2, graphite nanoparticles make a rather tangible contribution to improving the wear resistance of cross-linked nanocomposites. In this case, it should be argued that there are optimal concentrations of DP at which the nanocomposite achieves the greatest effect in improving the tribological properties. Comparing the data in Table 2, you can see that the best wear resistance is achieved when the concentration of DP is equal to 0.5 wt. $\%$ while a further increase in the concentration of DP leads to the deterioration of the wear resistance of nanocomposites. 
It has to be kept in mind that the method of thermo-mechanical research is one of the most informative methods for the analysis of changes in the physical condition of nanocomposites depending on concentration, size of the graphite particles and the medium temperature. Given the above, the considered nanocomposites belong to the category of semi-

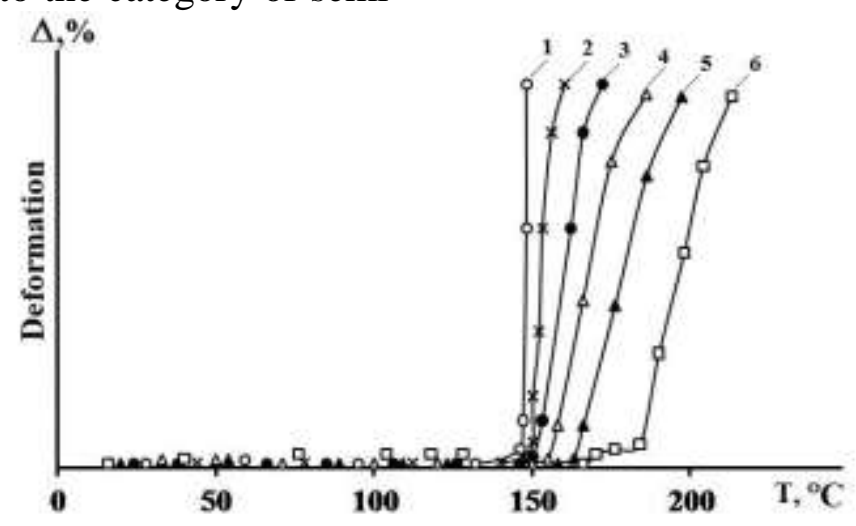

Fig. 1. Thermomechanical curves of nanocomposites based on BEP with different concentrations of graphite (wt.\%) and size of particles $(20-110 \mathrm{~nm})$ : ○-initial BEP (1), $\times-1.0(2), \bullet-5.0(3), \Delta-10.0$ (4), $\boldsymbol{\Delta}-20.0$ (5), $\square-30.0$ (6)

Analyzing the curves in the Figure above, it can be established that as the concentration of nanoparticles increases, regular changes in the thermo-deformation dependence toward the stretching of the viscous state are observed. At the same time, even with the introduction of 1.0 wt.\% graphite, an increase in the softening temperature of the samples from 144 to $147^{\circ} \mathrm{C}$ is observed. A further increase in the concentration of graphite from 5.0, 10.0, 20.0 to $30 \mathrm{wt} . \%$ leads, respectively, to an increase in the softening temperature of the samples from 149 , 157, 164 to $170^{\circ} \mathrm{C}$. The latter circumstance unambiguously indicates a strong adhesive bond

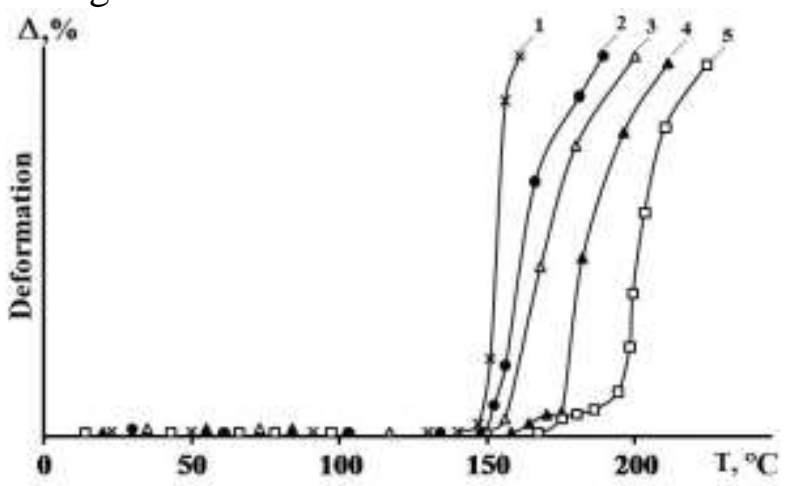

Fig. 2. Thermo-mechanical curves of BEP-based composites with various concentrations of graphite (wt.\%) and particle size (1500-3200 nm): $\times-1.0$ (1), •- 5.0 (2), $\Delta-10(3), \Delta-20(4)$, $\square-30(5)$ existing in the zone of contact of the polymerfiller. The differences arise from the fact that in nanocomposites containing $30 \mathrm{wt} \%$ of graphite on a thermo-mechanical curve, the region of viscous flow begins with a slight deformation up to $185^{\circ} \mathrm{C}$. Then, as the temperature increases, a rather sharp increase in the strain occurs. The deceleration of the deformation process at the moment of transition to the viscous state can apparently be interpreted by some increase in the melt viscosity at $30 \mathrm{wt} \%$ of graphite, as well as by agglomeration of nanoparticles at a high degree of filling. 
A comparative analysis in Fig. 2 shows the thermo-mechanical curves of the dependence of deformation on the temperature of BEP composites with a graphite particle size of 1500-3200 nm. As can be seen from Fig. 2, with an increase in the concentration of graphite, a regular stretching of the region of a viscous state is observed. As for increase in the concentration of graphite to $30 \mathrm{wt} \%$, the softening temperature increases from 144 (for the initial BEP) to $169^{\circ} \mathrm{C}$. The results of the study show that regardless of the particle size, the mechanism of softening process and the transition from solid to viscous state do not practically differ.

In contrast to nanoparticles, the introduction of comparatively larger dispersed graphite particles contributes to the fact that already at $20 \mathrm{wt}$. $\%$ of the filling, the transition to the viscous flow begins at $164^{\circ} \mathrm{C}$ with a slower deformation process. On the thermomechanical curve (Fig. 2.4), this region of the viscous state is expressed as a flat section. A further increase in the test temperature leads to a sharp increase in the deformation of the sample. At 30 wt. \% of graphite content (Fig. 2.5), this flat section on the thermo-mechanical curve stretches to the temperature of $190^{\circ} \mathrm{C}$. In this case, a further increase in temperature leads to a sharp increase in strain in the area of the viscous state.

In considering that the present work considered an influence of a crosslinking agent on the nature of changes in the structure and properties of composites, it is interesting, after the example of a BEP nanocomposite $+10 \mathrm{wt}$. $\%$ of graphite, to evaluate the role of DP in changing the nature of thermo-mechanical curves.

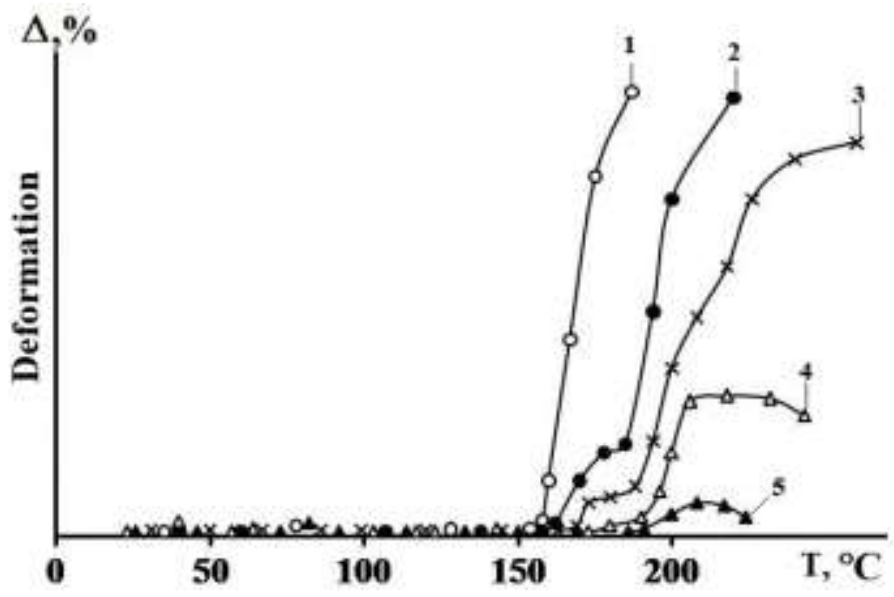

Fig. 3. Thermomechanical curves of composites based on BEP $+10 \%$ wt. graphite with a particle size (1500-3200nm) and various concentrations of PD (wt. \%):

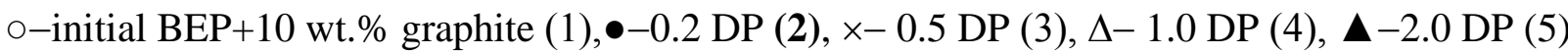

A comparative analysis of the curves presented in Fig. 3 shows that the introduction of a crosslinking agent contributes to noticeable changes in the nature of the thermo-deformation dependence. If DP content is up to $0.5 \mathrm{wt} . \%$, the nanocomposite samples still retain ability for the growing deformation in the sphere of the viscous-fluid state.

As expected, in Fig. 3.4 and 3.5 with the concentration of DP equal to $1.0 \mathrm{wt} \%$ and above, the samples with a densely networked Thus, on the basis of the foregoing, it can be concluded that the particle size of spatial structure practically lose their ability to get deformed and after softening, a plateau of highly elastic deformation appears on the curve at the beginning which, as the temperature of the experiment rises, goes into a glassy state. In fact, at $2.0 \mathrm{wt} . \%$ content of DP, the cross-linked filled polymer completely loses its ability to go into a plastic state. The obtained data are in good agreement with the results of experimental studies of the gel fraction of cross-linked polymers shown in Table 2 .

graphite and its concentration in the composition of BEP makes a significant 
contribution to changes in the structure and properties of the composites obtained on their basis. It becomes obvious that in the development of the composite material the correct selection of the ratio of components is of paramount importance, with which the greatest effect is achieved in the targeted improvement of some specific properties. Unlike finedispersed fillers, the introduction of nanoparticles makes it possible to achieve maximum improvement in the properties of nanocomposites at relatively low concentrations.

\title{
REFERENCES
}

1. Berlin A.A., Vol'fson S.A., Oshman V.G. Principy sozdaniya kompozicionnyh materialov. [Principles of creating composite materials]. Moscow: Himiya Publ., 1990, 240 p.

2. Gorokhovskiy A.V. Kompozitnie materiali [Composite materials]. Saratov State Technical University. 2008, 73 p. (In Russian).

3. Simonov-Emel'janov I.D., Kuleznev V.N. Osnovy sozdanija kompozicionnyh materialov [Basics of creating composite materials]. Moscow. 1986, 64 p.

4. Kahramanov N.T., Kahramanly Ju.N. Nanotechnology in the field of materials science. Scientific Works of the National Aviation Academ. 2009, vol.11, no. 3, pp. 7-15. (In Azerbaijan).

5. Gasimova G.Sh. Development of new composition materials on the basis of polypropylene, copolymers of ethylene with propylene, nanoclay and motor oil SAE5W30. Chemical Problems. 2017, no.4, pp.448-452. (In Azerbaijan).

6. Ivanchev S.S., Ozerin A.N. Nanostructures in polymer systems. Polymer Science. Series B. Polymer Chemistry. 2006, vol. 48, no. 8, pp. 1541-1544. (In Russian).
7. Kodolov V.I., Hohrjakov N.V., Kuznecov A.P. Prospects for the use of nanostructures and nanosystems when creating composites with predictable behavior. In book "Space challenges in 21 centuries. Vol. 3. Novel materials and technologies for space rockets and space development". Moscow: Torus press. 2007, pp. 201-205.

8. Pomogaylo A.D. Hybrid polymerinorganic nanocomposites. Uspekhi Khimii-Russian Chemical Reviews. 2000, vol. 69, no.1, p. 60.

9. Kodolov V.I., Khokhryakov N.V., Kuznetsov A.P. On the question of the mechanism of the influence of nanostructures on structurally changing environments in the formation of "intelligent" composites Nanotekhnika Nanotechnics. 2006, 3(7), pp. 27-35. (In Russian).

10. Okhlopkova, TA, Okhlopkova, A.A., Spiridonov, A.M., Nikiforov, L.A. Structural changes of ultrahigh molecular weight polyethylene under the influence of ceramic nanodispersions . Voprosy materialovedeniya. 2014, no.3 (79), pp.145-153. (In Russian).

11. Ohlopkova A.A., Ohlopkova T.A., Borisova R.V. Nauka i obrazovanie. 2015, no.2 (78), pp.73-78. (In Russian).

\section{ETILEN-PROPILEN BLOK BIRGOPOLIMERI VO QRAFIT OSASINDA NANOKOMPOZITLORIN FIZİKI-MEXANIKKI XASSOLORI}

\author{
${ }^{1}$ N.T. Qəhrəmanov, ${ }^{1}$ G.Ş. Qasımova, ${ }^{2}$ S.S. Pesetskiy, ${ }^{3}$ Y.N. Qəhrəmanlı, \\ ${ }^{3}$ R.V. Qurbanova, ${ }^{3}$ R.Ş. Hacıyeva, ${ }^{3}$ E.İ. Suleymanova \\ ${ }^{1}$ AMEA Polimer Materiallarl Institutu \\ AZ 5004 Sumqayıt, S.Vurğun küç., 124; e-mail: gulnara.qasimova.68@mail.ru
}


${ }^{2}$ Belarus Respublikası V.A. Belly adına Metal-polimerlar tadqiqatlar İnstitutu

Kirov str. 32a, Gomel, 246050, Belarus Republic

${ }^{3}$ Azarbaycan Dövlat Neft va Sanaye Universiteti AZ 1010, Bakl, Azadliq pr., 20

Propilen-etilen blok birgəpolimerin əsasında alınan kompozit materiallarının dă̆ılıcı gərginliyinə, nisbi uzanmasına, arintinin axıcılıq göstəricisinə və sürtünməyin davamlılı̆̆ına qrafitin hissaciklarinin ölçü va miqdarının təsiri öyranilmişdir. Göstərilib ki, tikilma reaksiyanın dinamik rejiminda aparllmass naticasinda nanokompozitlarin xassalarinin ahəmiyyatli daracada yaxşılaşdırılmasına imkan yaranır. Nanokompozitlarin özlü-axıcıllqdan bərk vaziyyətə keçirilmasinin qanunauyğunluğu termomexaniki üsulu ilo tədqiq edilmişdir. Nanokompozitlarin ən yüksək fiziki-mexaniki xassalarino nail olmaq üçün reaksiyada iştirak edən komponentlorin optimal qatilığı müayyən edilmişdir.

Açar sözlor: blok birgəpolimer, qrafit, termomexanika, nanokompozitlar, dartılmada möhkamlik haddi.

\title{
ФИЗИКО-МЕХАНИЧЕСКИЕ СВОЙСТВА НАНОКОМПОЗИТОВ НА ОСНОВЕ БЛОКСОПОЛИМЕРА ПРОПИЛЕНА С ЭТИЛЕНОМ И ГРАФИТА
}

\author{
${ }^{1}$ Н.Т. Кахраманов, ${ }^{1}$ Г.Ш. Касумова, ${ }^{2}$ С.С. Песецкий, ${ }^{3}$ Ю.Н. Кахраманль \\ ${ }^{3}$ Р.В. Курбанова, ${ }^{3}$ Р.ШІ. Гаджиева, ${ }^{3} Э$. И. Сулейманова \\ ${ }^{1}$ Институт Полимерных Материалов Национальной АН Азербайджана \\ AZ 5004 Сумгайыт, ул С. Вургуна, 124; e-mail: gulnara.qasimova.68@mail.ru \\ ${ }^{2}$ Институт Механики Металлополимерных Систем им В.А. Белого АН Республики Беларусь \\ 246050, г. Гомель, ул. Кирова 32a, Республика Беларусь \\ ${ }^{3}$ Азербайджсанский Государственный Университет Нефти и Промышленности \\ AZ 1010, Баку, пр. Азадльг, 20
}

Рассмотрено влияние концентрации и размера мелкодисперсных частии графита на разрушающее напряжение, относительное удлинение, показатель текучести расплава $и$ износостойкость композитных материалов на основе блок-сополимера пропилена $c$ этиленом. Показана возможность существенного улучшения свойств нанокомпозитов путем проведения реакции сиивания в динамическом режиме. Методом термомеханического анализа исследованы закономерности перехода нанокомпозитов из твердого в вязкотекучее состояние. Установлены оптимальные конщентрации реагирующих компонентов, при которой достигаются наиболее высокие физико-механические свойства нанокомпозитов.

Ключевые слова: блок-сополимер, графит, термомеханика, нанокомпозиты, разрушающее напряжение. 